Nama : Hasniar

Nim : 90100118042

Kelas : Ekonomi Islam A

\title{
Konsep Ekonomi Pada Ibnu Khaldun Dan Al-Ghazali
}

A. Pemikiran ibnu khaldun tentang ekonomi ( uang dan harga)

Ibnu khaldun adalah seorang ilmuwan muslim yang memiliki banyak sekali pemikiran dalam bidang ekonomi, politik dan kebudayaan, dan salah satu pemikirannya yang paling menonjol adalah dalam bidang ekonomi.sehingga Pemikiran ibnu khaldun sangat penting bagi pengembangan ekonomi islam kedepannya olehnya ia dikenal sebagai bapak sosiologi sekaligus bapak ekonomi. ${ }^{1}$

a. Pemikiran ibnu khaldun tentang uang

Ukuran ekonomi terhadap barang dan jasa sangatlah perlu bagi manusia jika ia ingin memperdagangkannya, pengukuran nilai tersebut harus memiliki sejumlah kualitas tertentu ukuran ini harus diterima oleh semua sebagai tender legal dan penerbitannya harus bebas dari semua pengaruh subjektif. Bagi ibnu khaldun logam emas dan perak adalah ukuran nilai " allah menciptakan dua batuan logam tersebut, emas dan perak, sebagai ukuran nilai semua akumulasi modal. ( emas dan peraklah) inilah yang dipilih untuk dianggap sebagai harta kekayaan oleh penduduk dunia. Oleh karenanya ibnu khaldun mendukung penggunaan emas dan perak sebagai standar moneter.

Ibnu Khaldun juga mengatakan bahwa uang adalah yang menentukan taraf kemakmuran. Ia juga menyarankan di gunakannya uang standar emas atau perak, selain itu juga ia menyarankan selain digunakan uang standar emas dan perak, juga menyarankan konstannya harga emas dan perak .harga lain boleh berpluktasi tetapi tidak dengan emas dan perak

\footnotetext{
${ }^{1}$ Fitriani, revi. “ pemikiran ekonomi islam ibnu khaldun”. Maro: jurnal ekonomi syariah dan bisnis, 2019, Vol 2 No 2 Hlm 129.
} 
b. Pemikiran ibnu khaldun tentang harga

Pemikiran ibnu khaldun mengenai harga adalah hasil dari hukum permintaan dan penawaran. Dengan adanya pengecualian salah satu hukum tersebut yakni harga emas dan perak, yang merupakan standar moneter . semua barang-barang yang lainnya terkena fluktuasi harga yang bergantung pada pasar. Artinya bila suatu barang yang tersedia kurang maka permintaan akan barang tersebut meningkat, maka harganya tinggi, jika suatu barang banyak yang tersedia maka permintaan akan barang tersebut menurun sehingga harga menjadi rendah ${ }^{2}$

B. Pemikiran Al-Ghazali

Perhatian al-ghazali terhadap kehidupan masyarakat tidak hanya berfokus pada satu bidang tertentu saja tetapi meliputi seluruh aspek kehidupan manusia. Olehnya tidak ada karya tulis yang secara khusus membahas tentang ekonomi islam. Perhatiannya dalam bidang ekonomi terkandung dalam berbagai studi fiqih karena pada hakikatnya ekonomi islam merupakan bagian yang tidak dapat di pisahkan dari fiqh islam

Adapun hal menarik dari pemikiran al-ghazali didasarkan pada pendekatan tasawuf, karena pada masa hidupnya, orang-orang kaya, berkuasa dan saraf prestise sulit menerima pendekatan fiqh dan filosofi dalam mempercayai yaumul hisab. Berkaitan dengan hal tersebut al-ghazali memfokuskan perhatiannya pada perilaku individu yang dibahas menurut perspektif al-qur'an, sunnah, fatwa-fatwa sahabat dan tabi'in serta petuah para sufi terkemuka masa sebelumnya ${ }^{3}$

Berdasarkan pandangan Al-ghazali tentang wawasan sosio ekonomi, dapat di angkat beberapa tema ekonomi diantaranya mencakup perdagangan sukarela, aktivitas produksi, barter, dan peran negara dalam keuangan public ${ }^{4}$

\footnotetext{
${ }^{2}$ Iqbal, ichsan.”Pemikiran ekonomi islam tentang uang, harga dan pasar". Journal khatulistiwa LP2LAIN Pontianak, 2012 Vol 2 No 1 Hlm 3-9.

${ }^{3}$ Sirajjudin, “ konsep pemikiran al-ghazali "jurnal laa maisyir vol 3 no 1 juni 2016, hal 52-53

${ }^{4}$ Rahmawati, lilih.” Konsep ekonomi Al-ghazali,maliyah: jurnal hukum bisnis islam, 2012 Vol 2 No 1 Hlm 10.
} 


\section{DAFTAR PUSTAKA}

Fitriani, R. (2019). Pemikiran Ekonomi Islam Ibnu Khaldun. Maro: Jurnal Ekonomi syariah dan Bisnis, 2(2), 128-142.

Iqbal, I. (2012). Pemikiran Ekonomi Islam tentang uang, harga dan pasar. Jurnal Khatulistiwa LP2M IAIN Pontianak, 2(1)

Sirajjudin, (2016) “ konsep pemikiran al-ghazali ”jurnal laa maisyir 3 (1 )

Rahmawati, L. (2012). Konsep Ekonomi Al-Ghazali. Maliyah: Jurnal Hukum Bisnis Islam, 2(1). 